\title{
Charakter prawny decyzji w sprawie równoważnika za brak lokalu mieszkalnego dla strażaka Państwowej Straży Pożarnej
}

\author{
The legal nature of the decision on the equivalent for the lack of accommodation \\ for a firefighter of the State Fire Service \\ Правовая природа решения, касающегося эквивалента за отсутствие жилья \\ у пожарного Государственной противопожарной службы
}

\author{
DARIUSZ PIOTR KAtA \\ Dr, Akademia Ekonomiczno-Humanistyczna w Warszawie \\ e-mail: d.kala@vizja.pl, https://orcid.org/0000-0002-2886-9117
}

\begin{abstract}
Streszczenie: Artykuł dotyczy charakteru prawnego decyzji w sprawie równoważnika pieniężnego za brak lokalu dla strażaków Państwowej Straży Pożarnej. Publikacja wypełnia lukę w dotychczasowej nauce prawa, jest jedynym i pierwszym opracowaniem naukowym na ten temat. W artykule omówiono aktualne uregulowanie prawne tego świadczenia, a także jego unormowanie $w$ historii, występujące w zakresie tego zagadnienia rozbieżne orzecznictwo sądów. Całość problematyki odniesiono do regulacji prawnych równoważnika w innych służbach mundurowych, a także istniejących w obrębie tych regulacji linii orzeczniczych sądów. W artykule przedstawiono wnioski z rozważań oraz postawiono tezę o mieszanym charakterze decyzji w sprawie równoważnika pieniężnego za brak lokalu dla strażaków Państwowej Straży Pożarnej.
\end{abstract}

Słowa kluczowe: straż pożarna, ochrona przeciwpożarowa, równoważnik pieniężny za brak lokalu, finanse publiczne, świadczenia mieszkaniowe w straży pożarnej, służby mundurowe

Summary: The article concerns the legal nature of the decision on the cash equivalent for the lack of premises for firefighters of the State Fire Service. This article fills the gap in the science of law so far, it is the first and only scientific study on this subject. The article discusses the current legal regulation of this benefit, as well as its regulation in history in the divergent jurisprudence of courts in this matter. All issues were related to equivalent legal regulations in other uniformed services, as well as the jurisprudence lines existing within these regulations. The article ends with the author's conclusions and a mixed thesis of the decision on the cash equivalent for the lack of premises for firefighters of the State Fire Service.

Key words: fire service, fire protection, cash equivalent for the lack of premises, public finances, housing services in the fire brigade, uniformed services

\begin{abstract}
Резюме: Статья касается правового характера решения о денежном эквиваленте за отсутствие жилья у пожарных Государственной противопожарной службы. Публикация восполняет пробел в до сих пор существовавшей науке о праве и является единственным и первым научным исследованием на эту тему. В статье рассматривается современное правовое регулирование данного пособия, а также его нормализация в истории и разноречивые судебные решения по данному вопросу. Весь вопрос был отнесен к правовому регулированию эквивалента в других силовых и военизированных службах, а также к существующим в рамках этого регулирования линиям судебных решений. В статье представлены выводы из проведенных рассуждений и выдвинут тезис о неоднозначном характере решений о денежном эквиваленте за отсутствие жилых помещений для пожарных Государственной противопожарной службы.
\end{abstract}

Ключевые слова: противопожарная служба, пожарная охрана, денежный эквивалент за отсутствие жилых помещений, государственные финансы, жилищные пособия в противопожарной службе, силовые и военизированные службы 


\section{Wstęp}

Przedmiotem artykuł jest określony w art. 78 ustawy z dnia 24 sierpnia $1991 \mathrm{r}$. o Państwowej Straży Pożarnej ${ }^{1}$ równoważnik za brak lokalu mieszkalnego dla strażaka Państwowej Straży Pożarnej (dalej: PSP). Jest to jedno ze świadczeń mieszkaniowych uregulowanych w rozdziale 8 ustawy o Państwowej Straży Pożarnej Mieszkania strażaków w stużbie państwowej.

Uzasadnieniem wyboru tematu jest fakt, że zagadnienie charakteru prawnego tego świadczenia nie spotkało się dotychczas z opracowaniem w nauce prawa. Artykuł jest więc uzupełnieniem luki w nauce prawa. Sam równoważnik za brak lokalu jest natomiast jednym z najczęściej rozpatrywanych zagadnień przez orzecznictwo sądów administracyjnych pośród zagadnień dotyczących $\mathrm{PSP}^{2}$. Publikacja ma więc duże znaczenie praktyczne i może stać się pomocą w praktyce orzeczniczej sądów oraz w praktyce działania organów administracji, tj. komendantów PSP.

Celem opracowania jest odpowiedź na pytanie, jaki charakter prawny ma decyzja w sprawie równoważnika za brak lokalu mieszkalnego dla strażaka PSP. Czy jest to decyzja konstytutywna czy deklaratoryjna, czy może mieszana. Charakter prawny decyzji w sprawie tego świadczenia jest więc głównym problemem artykułu, z którym wiążą się odpowiedzi na problemy szczegółowe, takie jak: charakter decyzji administracyjnych w ogólności, skutki prawne uznania decyzji administracyjnej jako konstytutywnej lub deklaratoryjnej, występowanie zagadnienia równoważnika za brak lokalu mieszkalnego w ramach innych formacji mundurowych oraz wnioski płynące z praktyki orzeczniczej w tym zakresie, występowanie równoważnika za brak lokalu mieszkalnego dla strażaka PSP w ujęciu historycznym.

$\mathrm{W}$ artykule wykorzystano tradycyjne metody naukowe w ramach nauki prawa, jak: metoda historyczno-prawna, metoda hermeneutyczna, metoda argumentacyjna.

\section{Prezentacja instytucji równoważnika}

Zgodnie $\mathrm{z}$ art. 78 ust. 1 u.PSP 1 . strażakowi mianowanemu na stałe przysługuje równoważnik pieniężny, zwany dalej „równoważnikiem za brak lokalu mieszkalnego", jeżeli on sam lub członkowie jego rodziny, o których mowa w art. 75, nie posia-

1 Tekst jednolity: Dz. U. z 2020 r. poz. 1123 (dalej: u.PSP).

2 Zob. CBOSA, http://orzeczenia.nsa.gov.pl/cbo/search [dostęp: 1.12.2020 r.]. 
dają w miejscu pełnienia służby albo w miejscowości pobliskiej lokalu mieszkalnego lub domu na podstawie przysługującego im tytułu prawnego oraz nie zachodzi przypadek określony w art. 82 ust. 5.

Słusznie wskazano w doktrynie prawa, że prawo do lokalu mieszkalnego funkcjonariuszy służb mundurowych nie może być traktowane jako niezasłużone wyróżnienie czy przywilej. Przyznanie funkcjonariuszowi uprawnień mieszkaniowych wynika z konieczności jego dyspozycyjności na potrzeby formacji mundurowej³ ${ }^{3}$.

W orzecznictwie sądowym podkreśla się jednolicie, że:

Nie ulega wątpliwości, że służbę pożarniczą cechuje daleko idąca dyspozycyjność jej funkcjonariuszy, z racji niemożliwego zaplanowania szczególnie działań gaśniczo-ratowniczych, skoro działania te dotyczą zdarzeń nagłych i nieprzewidywalnych, a których skala może wymagać udziału wszystkich strażaków danej jednostki i to niezależnie od pory dnia i nocy. Z tego względu, oczywistym wymogiem służby pożarniczej jest gotowość jej pracowników do wykonywania zadań w każdym czasie i o każdej porze, co wymusza konieczność zamieszkiwania tych osób w pobliżu jednostki pełnienia służby, aby zapewnić uzyskanie gotowości wykonywania działań ratowniczo-gaśniczych w jak najkrótszym czasie. W tym właśnie celu, w omawianym art. 78 ust. 1 ustawy o PSP związano prawo otrzymania przez strażaka równoważnika pieniężnego $\mathrm{z}$ faktem nieposiadania przez niego lokalu mieszkalnego w miejscu pełnienia służby lub w miejscowości pobliskiej, aby strażak mógł zapewnić sobie we własnym zakresie zamieszkiwanie w pobliżu jednostki pełnienia służby, niezależnie od tego, czy posiada lokal mieszkalny poza miejscem pełnienia służby i poza miejscowością pobliską. Równoważnik przyznany za brak takiego miejsca ma natomiast służyć, aż do momentu, w którym te faktyczne potrzeby mieszkaniowe nie będą zaspokojone $e^{4}$.

Słusznie się więc w powyższej doktrynie i powyższym orzecznictwie wskazuje, że równoważnik za brak lokalu mieszkalnego dla strażaków PSP wynika wprost z troski państwa o zapewnienie sprawności działania służb mundurowych. Konieczność ta wynika ze szczególnej roli, jaką pełnią formacje mundurowe, a która polega na zapewnieniu bezpieczeństwa obywateli w różnych obszarach. Sprawność ta może być zapewniona, jeżeli formacje mundurowe i ich

3 Por. P. Szustakiewicz, Świadczenia pieniężne związane z prawem do lokalu mieszkalnego emerytów i funkcjonariuszy służb mundurowych $w$ orzecznictwie sąów administracyjnych, IUSNOVUM 2013, nr 3, s. 167 i nn.

4 Wyrok WSA w Warszawie z dnia 25 października 2013 r., VIII SA/Wa 548/13, Legalis nr 795634; wyrok WSA w Białymstoku z dnia 6 września 2018 r., II SA/Bk 338/18, Legalis nr 1824985 oraz II SA/ Bk 337/18, Legalis nr 1824984; wyrok WSA w Szczecinie z dnia 12 lutego 2014 r., II SA/Sz 1252/13, Legalis nr 980405. 
funkcjonariusze będą dyspozycyjni. Dyspozycyjność ta jest niezbędna z racji na nieprzewidywalność zdarzeń pożarowych, ich nagłość rozwoju oraz stan zagrożenia, które powodują.

Rangę tego uprawnienia podnosi także fakt, że lokal, który należy przydzielać strażakowi PSP, musi spełniać odpowiednie normy zaludnienia oraz posiadać stan techniczny pozwalający w nim zamieszkać. W orzecznictwie podkreśla się także, że równoważnik za brak lokalu jest uprawnieniem pochodnym (zastępczym) w stosunku do uprawnienia do przyznania lokalu wynikającym $\mathrm{z}$ art. 74 u.PSP5.

Równoważnik za brak lokalu mieszkalnego jest instytucją prawną szeroko występującą w systemie prawa polskiego. Jego istnienie nie ogranicza się wyłącznie do formacji takiej jak PSP. Można powiedzieć że jest instytucją „ogólnomundurową", ponieważ występuje także w ramach pragmatyk zawodowych innych formacji mundurowych ${ }^{6}$.

Policjantowi przysługuje równoważnik pieniężny, jeżeli on sam lub członkowie jego rodziny nie posiadają lokalu mieszkalnego $\mathrm{w}$ miejscu pełnienia służby lub w miejscowości pobliskiej ${ }^{ך}$.

Funkcjonariuszowi przysługuje równoważnik pieniężny, jeżeli on sam lub członkowie jego rodziny nie posiadają lokalu mieszkalnego w miejscu pełnienia służby lub w miejscowości pobliskiej.

Funkcjonariuszowi w służbie stałej przysługuje równoważnik pieniężny, jeżeli on sam lub członkowie jego rodziny nie posiadają lokalu mieszkalnego w miejscu pełnienia służby lub w miejscowości pobliskiej, odpowiadającego co najmniej przysługującej funkcjonariuszowi powierzchni mieszkaniowej9.

Funkcjonariuszowi w służbie stałej przysługuje równoważnik pieniężny z tytułu braku mieszkania, jeżeli:

5 Por. wyrok WSA w Warszawie z dnia 25 października 2013 r., VIII SA/Wa 548/13, Legalis nr 795634; wyrok NSA z dnia 15 czerwca 2012 r., I OSK 2094/11, Legalis nr 1937803; wyrok WSA w Poznaniu z dnia 12 marca 2014 r., IV SA/Po 1103/13, Legalis nr 978915; wyrok WSA w Gliwicach z dnia 28 kwietnia 2017 r., IVSA/GI 1012/16, Legalis nr 1633470.

6 Por. P. Szustakiewicz, Świadczenia pieniężne..., s. 167 i nn.

7 Art. 92 ust. 1 ustawy z dnia 6 kwietnia 1990 r. o Policji, tekst jednolity: Dz. U. z 2020 r. poz. 360 z późn. zm. Zob. M. Chrabkowski, Równoważnik pieniężny za brak lokalu mieszkalnego, cz. 1 i 2, Policja 2012, nr 3, s. 13-22; nr 4, s. 8-20; M. Chrabkowski, Glosa do wyroku WSA w Warszawie z 30.06.2011 r., II SA/Wa 935/11, Gdańskie Studia Prawnicze. Przegląd Orzecznictwa 2012, nr 3, s. 11-21.

8 Art. 96 ust. 1 ustawy z dnia 12 października 1990 r. o Straży Granicznej, tekst jednolity: Dz. U. z 2020 r. poz. 305 z późn. zm.

9 Art. 179 ust. 1 ustawy z dnia 8 grudnia 2017 r. o Służbie Ochrony Państwa, tekst jednolity: Dz. U. z 2020 r. poz. 384 z późn. zm. Przed zastąpieniem Biura Ochrony Rządu przez Służbę Ochrony Państwa można wskazać na art. 79 ust. 1 ustawy z dnia 16 marca 2001 r. o Biurze Ochrony Rządu, tekst jednolity: Dz. U. z 2017 r. poz. 985 z późn. zm. 
1) on sam lub jego małżonek nie posiada w miejscowości pełnienia służby lub miejscowości pobliskiej tytułu prawnego do lokalu mieszkalnego lub domu,

2) funkcjonariuszowi lub jego małżonkowi nie przyznano pomocy finansowej, o której mowa w art. 184 ust. 1.

Funkcjonariuszowi w służbie stałej przeniesionemu z urzędu do pełnienia służby $\mathrm{w}$ innej miejscowości przysługuje równoważnik pieniężny, o którym mowa w ust. 1, jeżeli w nowej miejscowości pełnienia służby:

1) nie przyznano mu pomocy finansowej na uzyskanie lokalu mieszkalnego,

2) nie przydzielono mu lokalu mieszkalnego lub kwatery tymczasowej ${ }^{10}$.

Funkcjonariuszowi w służbie stałej przysługuje równoważnik pieniężny za brak lokalu mieszkalnego, jeżeli on sam lub członkowie jego rodziny nie posiadają lokalu mieszkalnego w miejscu pełnienia służby lub w miejscowości pobliskiej ${ }^{11}$.

Funkcjonariuszowi w służbie stałej przysługuje równoważnik pieniężny za brak lokalu mieszkalnego, jeżeli on sam lub członkowie jego rodziny nie posiadają lokalu mieszkalnego w miejscu pełnienia służby lub w miejscowości pobliskiej ${ }^{12}$.

Funkcjonariuszowi przyznaje się, w drodze decyzji, dodatek mieszkaniowy, jeżeli jest to uzasadnione potrzebami CBA oraz jeżeli:

1) on sam, małżonek lub osoba pozostająca $\mathrm{z}$ nim we wspólnym gospodarstwie domowym nie posiadają lokalu mieszkalnego lub domu jednorodzinnego w miejscu pełnienia służby lub w miejscowości pobliskiej,

2) został przeniesiony do pełnienia służby w innej miejscowości, w której on sam, współmałżonek lub osoba pozostająca z nim we wspólnym gospodarstwie domowym nie posiadają lokalu mieszkalnego lub domu jednorodzinnego,

3) został przeniesiony do pełnienia służby w innej miejscowości i nie został zakwaterowany na koszt $\mathrm{CBA}^{13}$.

Analiza uregulowania równoważnika w innych niż w PSP pragmatykach służb mundurowych jest zasadna, gdyż słusznie i jednolicie wskazuje się w orzecznictwie sądów, że $\mathrm{z}$ racji na podobieństwo tych regulacji w ustawach służb

10 Art. 178 ust. 1-2 ustawy z dnia 9 kwietnia 2010 r. o Służbie Więziennej, tekst jednolity: Dz. U. z 2020 r. poz. 848 z późn. zm.

11 Art. 106 ust. 1 ustawy z dnia 24 maja 2002 r. o Agencji Bezpieczeństwa Wewnętrznego oraz Agencji Wywiadu, tekst jednolity: Dz. U. z 2020 r. poz. 27 z późn. zm.

12 Art. 66 ust. 1 ustawy z dnia 9 czerwca 2006 r. o służbie funkcjonariuszy Służby Kontrwywiadu Wojskowego oraz Służby Wywiadu Wojskowego, tekst jednolity: Dz. U. z 2020 r. poz. 1221 z późn. zm.

13 Art. 93d ust. 1 ustawy z dnia 9 czerwca 2006 r. o Centralnym Biurze Antykorupcyjnym, tekst jednolity: Dz. U. z 2019 r. poz. 1921 z późn. zm. 
mundurowych można wykorzystywać orzecznictwo sądów wydane np. w odniesieniu do uprawnień policjantów do rozstrzygania problemów występujących np. w $\mathrm{PSP}^{14}$.

\section{Rys historyczno-prawny}

Równoważnik za brak lokalu pojawił się już wwersji pierwotnej ustawy z dnia 24 sierpnia 1991 r. o Państwowej Straży Pożarnej ${ }^{15}$.

W pierwotnej wersji dekretu $\mathrm{z}$ dnia 27 grudnia 1974 r. o służbie funkcjonariuszy pożarnictwa ${ }^{16}$, który poprzedzał obowiązywanie ustawy o PSP, brak było uregulowania takiej instytucji jak równoważnik za brak lokalu. Takiego unormowania nie było także w wersji niniejszego dekretu bezpośrednio przed jego uchyleniem i uchwaleniem ustawy o PSP.

Kwestii równoważnika nie regulowało także Rozporządzenie Rady Ministrów z dnia 10 października 1952 r. w sprawie stosunku służbowego członków Korpusu Technicznego Pożarnictwa ${ }^{17}$ wydane na podstawie art. 5 ust. 2 ustawy z dnia 4 lutego 1950 r. o ochronie przeciwpożarowej i jej organizacji ${ }^{18}$. Rozporządzenie to regulowało m.in. obowiązki i prawa ówczesnych funkcjonariuszy pożarnictwa, ale nie zawierało uregulowań co do prawa do lokalu lub świadczeń z nim związanych. Podobnych regulacji nie zawierała także ustawa o ochronie przeciwpożarowej $\mathrm{z}$ dnia 4 lutego $1950 \mathrm{r}$.

Instytucji równoważnika nie regulowała także ustawa z dnia 13 marca $1934 \mathrm{r}$. o ochronie przed pożarami i innemi klęskami ${ }^{19}$.

14 Wyrok NSA z dnia 13 lutego 2019 r., I OSK 864/17, Legalis nr 1889822; wyrok WSA w Warszawie z dnia 15 lutego 2019 r., II SA/Wa 784/18, Legalis nr 2237363.

15 Dz. U. z 1991 r. Nr 88, poz. 400.

16 Dz. U. z 1974 r. Nr 50, poz. 321 - dekret wszedł w życie 1 stycznia 1975 r.

17 Dz. U. z 1952 r. Nr 42, poz. 291.

18 Dz. U. z 1951 r. Nr 58, poz. 404.

19 Dz. U. z 1934 r. Nr 41, poz. 365. 


\section{Problem charakteru prawnego decyzji w sprawie równoważnika}

Świadczenia mieszkaniowe dla strażaków PSP przyznawane są w formie decyzji administracyjnej wydawanej przede wszystkim na podstawie przepisów u.PSP oraz Kodeksu postępowania administracyjnego. Wynika to wprost $\mathrm{z}$ takich przepisów prawa jak art. 80 ust. 1 i 5, art. 81 , art. 82 ust. 1 i 2, art. 83 ust. 1, art. 83a ust. 1 i 6 u.PSP. Wynika to także z art. 1 pkt 1 ustawy z dnia 14 czerwca 1960 r. Kodeks postępowania administracyjnego ${ }^{20}$, zgodnie z którym K.p.a. normuje postępowanie przed organami administracji publicznej w należących do właściwości tych organów sprawach indywidualnych rozstrzyganych w drodze decyzji administracyjnych albo załatwianych milcząco. Zostało to także wielokrotnie jednoznacznie potwierdzone w orzecznictwie sądów administracyjnych ${ }^{21}$. Także kwestie równoważnika za brak lokalu rozstrzyga się w formie decyzji administracyjnej wydawanej w oparciu o u.PSP i K.p.a. ${ }^{22}$.

$\mathrm{W}$ orzecznictwie sądów administracyjnych powstała istotna rozbieżność poglądów w zakresie, jaki charakter prawny ma decyzja w sprawie równoważnika za brak lokalu mieszkalnego dla strażaka PSP. W niektórych orzeczeniach uznano, że ma ona charakter deklaratoryjny ${ }^{23}$, a w innych konstytutywny ${ }^{24}$. Naczelny Sąd Administracyjny ${ }^{25}$ oraz Sąd Najwyższy ${ }^{26}$ stanęły na stanowisku, że decyzja ta ma charakter deklaratoryjny. Aczkolwiek wyroki NSA i SN zostały wydane w zwykłych trzyosobowych składach, nie są to uchwały w składzie powiększonym czy ustanowienie zasady prawnej. W przedmiocie tych rozbieżności brak stanowiska doktryny prawa.

20 Tekst jednolity: Dz. U. z 2020 r. poz. 256 z późn. zm. (dalej: K.p.a.).

21 Np. wyrok WSA w Warszawie z dnia 12 maja 2009 r., II SA/Wa 66/09, Legalis nr 234263; wyrok NSA z dnia 26 czerwca 2014 r., I OSK 947/13, Legalis nr 1161361; wyrok NSA z dnia 23 stycznia 2014 r., I OSK 130/13, Legalis nr 1327767.

22 Np. wyrok WSA w Warszawie z dnia 6 marca 2019 r., II SA/Go 57/19, Legalis nr 1887653; wyrok WSA w Warszawie z dnia 15 lutego 2019 r., II SA/Wa 784/18, Legalis nr 1887653; wyrok NSA w Warszawie z dnia 13 lutego 2019 r., I OSK 864/17, Legalis nr 1889822.

23 Wyrok WSA w Warszawie z dnia 15 lutego 2019 r., II SA/Wa 784/18, Legalis nr 1887653.

24 Wyrok WSA w Gdańsku z dnia 15 grudnia 2016 r., III SA/Gd 747/16, Legalis nr 1594165; wyrok WSA w Warszawie z dnia 6 marca 2019 r., II SA/Go 57/19, Legalis nr 1887653; wyrok WSA w Krakowie z dnia 19 listopada 2013 r., III SA/Kr 50/13, Legalis nr 794872; wyrok WSA w Białymstoku z dnia 1 grudnia 2016 r., II SA/Bk 706/16, Legalis nr 1592480 - wyrok z Białegostoku został zaskarżony do NSA, a NSA uznał, że decyzja ma charakter deklaratoryjny - wyrok NSA w Warszawie z dnia 13 lutego 2019 r., I OSK 864/17, Legalis nr 1889822.

25 Wyrok NSA w Warszawie z dnia 13 lutego 2019 r., I OSK 864/17, Legalis nr 1889822.

26 Wyrok SN z dnia 26 sierpnia 2015 r., I BP 7/14, Legalis nr 1337741. 


\section{Konstytutywność a deklaratoryjność oraz ich skutki prawne}

Problem aktów deklaratoryjnych i konstytutywnych znany jest od dawna doktrynie prawa oraz orzecznictwu sądowemu ${ }^{27}$.

W doktrynie prawa wskazuje się, że podział na akty konstytutywne i deklaratoryjne jest powszechnie zaakceptowany i uznaje się, że jest on praktycznie użyteczny. Kwestia tego podziału to nie jest tzw. problem zerojedynkowy, ponieważ granice pomiędzy konstytutywnością a deklaratoryjnością nie są jednoznacznie wytyczone. Prowadzi to do ich zacierania się oraz kształtowania poglądów o występowaniu aktów o charakterze mieszanym lub w ogóle o względności tego podziału lub jego zbędności ${ }^{28}$.

Problematyka konstytutywnego lub deklaratoryjnego charakteru decyzji administracyjnych pojawia się także w piśmiennictwie. Zdaniem J. Borkowskiego: „Skutki decyzji konstytutywnych powstawać mają od daty ich doręczenia, a decyzji deklaratoryjnych z mocą wsteczną, od daty pojawienia się faktów prawotwórczych. Akt konstytutywny tworzy nowy stan prawny adresata, a deklaratoryjny - potwierdza go tylko i usuwa co do niego wątpliwości. Podział ten, choć z pozoru prosty i użyteczny, wcale takim się nie okazuje przy bliższym jego zbadaniu. Przede wszystkim dlatego, że nie ma decyzji, które wszystkimi swoimi skutkami mieściłyby się w jednej albo w drugiej kategorii. Akt deklaratoryjny zawsze ma cechę konstytutywności, bo dopiero od jego doręczenia adresatowi ustają wątpliwości co do prawa, które jemu służy, zaś akt konstytutywny wsparty jest o niektóre przesłanki istniejące już przed jego wydaniem i doręczeniem" (B. Adamiak, J. Borkowski, Kodeks postępowania administracyjnego, Komentarze, wyd. 7, Warszawa 20005, s. 478-479) 29.

Podstawą odróżnienia aktów konstytutywnych od deklaratoryjnych jest to, że te pierwsze konstytuują (kształtują) stosunek prawny. Kształtowanie to może polegać na konstytuowaniu nowego stosunku prawnego bądź zmianie lub zniesieniu istniejącego stosunku prawnego. Akt konstytutywny konkretyzuje istniejącą normę prawną. Akty deklaratoryjne potwierdzają tylko stosunek prawny istniejący na mocy prawa. $Z$ tym rozróżnieniem wiąże się więc element temporalny. Akt konstytutywny może kształtować stosunek prawny wyłącznie na przyszłość, od momentu kiedy zostanie on wydany (ex nunc). Akty deklaratoryjne mogą natomiast wywoływać skutki z mocą wsteczną (ex tunc), ponieważ mogą potwierdzić istnienie stosunku prawnego, który z mocy prawa istniał przed wydaniem

27 A. Błaś, J. Boć, M. Stahl, K. Ziemski, Akty deklaratoryjne a akty konstytutywne, w: Prawne formy dziatania administracji, red. R. Hauser, Z. Niewiadomski, A. Wróbel, 2013 [baza danych Legalis].

28 Tamże.

29 Wyrok WSA w Warszawie z dnia 6 listopada 2008 r., II SA/Wa 1202/08, Legalis nr 282366. 
aktu administracyjnego. Stosunek prawny może bowiem istnieć już w momencie ustanowienia danego prawa, które uchwalił prawodawca i związał z nim ziszczenie się przesłanek określonych w przepisach prawa. Akt deklaratoryjny ma więc pewien porządkujący, potwierdzający charakter w tym sensie, że wydanie takiego aktu znosi element niepewności mogący wiązać się z istnieniem danego przepisu. Wydanie aktu deklaratoryjnego „zatwierdza” niejako to, co ustanowił ustawodawca i stanowi potwierdzenie woli władzy ustawodawczej przez władzę wykonawczą ${ }^{30}$.

Jedną z konsekwencji takiego rozróżnienia jest to, że w przypadku decyzji konstytutywnych - kształtujących stosunek administracyjnoprawny w chwili ich wydania, należy stosować przepisy obowiązujące w tej właśnie chwili (przepisy nowe), a w przypadku decyzji deklaratoryjnych - stwierdzających ukształtowanie się stosunku administracyjnoprawnego z mocy samego prawa we wcześniejszym okresie, stosować należy przepisy obowiązujące w chwili konkretyzacji tego stosunku, na mocy których doszło do powstania stosunku prawnego (przepisy poprzednie) ${ }^{31}$.

\section{Charakter decyzji w sprawie równoważnika w innych niż PSP służbach mundurowych}

Tak jak to wskazano wcześniej, instytucja równoważnika za brak lokalu występuje także w obrębie innych służb mundurowych. Także tam pojawia się kwestia charakteru prawnego decyzji w tej sprawie.

W pierwszej kolejności można wskazać na orzecznictwo z zakresu policji. $\mathrm{W}$ jednym $\mathrm{z}$ orzeczeń podkreślono, że:

Zresztą kwestia charakteru (konstytutywnego bądź deklaratoryjnego) decyzji wydawanej na podstawie ww. przepisu ${ }^{32}$ była wielokrotnie przedmiotem analizy Naczelnego Sądu Administracyjnego. Aktualna linia orzecznicza wskazuje zaś jednolicie na deklaratoryjny charakter takiej decyzji, a zatem potwierdzający prawo do równoważnika

30 Por. A. Błaś, J. Boć, M. Stahl, K. Ziemski, Akty deklaratoryjne...; M. Grześków, Nawiązywanie stosunków zatrudnienia w służbach zmilitaryzowanych, 2020 [baza danych Legalis]; P. Daniel, F. Geburczyk, Akt informacji jako forma działania administracji publicznej, 2019 [baza danych Legalis]; wyrok NSA z dnia 1 sierpnia 2019 r., I OSK 3175/18, Legalis nr 2364759; wyrok NSA z dnia 24 sierpnia 2020 r., I OSK 3285/19, Legalis nr 2477768.

31 Wyrok NSA z dnia 21 marca 2018 r., I OSK 1132/16, Legalis nr 1789244; uchwała NSA w Składzie Siedmiu Sędziów z dnia 10 kwietnia 2006 r., I OPS 1/06, Orzecznictwo Naczelnego Sądu Administracyjnego i Wojewódzkich Sądów Administracyjnych 2006, nr 3, poz. 71.

Chodzi tutaj o art. art. 92 ust. 1 ustawy z dnia 6 kwietnia 1990 r. o Policji. 
w okresie, w którym funkcjonariusz spełniał przesłanki do jego przyznania (zob. wyroki Naczelnego Sądu Administracyjnego z dnia: 10 listopada 2015 r., sygn. akt I OSK 1294/14, Legalis nr 1449292; 21 marca 2018 r., sygn. akt I OSK 1132/16, Legalis nr 1789244; 8 sierpnia 2018 r., sygn. akt I OSK 2206/16, Legalis nr 1866526; 30 października 2018 r., sygn. akt I OSK 1217/18, Legalis nr 1864296; 31 stycznia 2019 r., sygn. akt I OSK 2046/18, Legalis nr 1884701; 1 sierpnia 2019 r., sygn. akt I OSK 3175/18, Legalis nr 2364759) $)^{33}$.

W orzecznictwie pojawił się także pogląd, że: „Decyzja w przedmiocie równoważnika pieniężnego za brak lokalu i jego wysokości ma charakter konstytutywny, co oznacza, że wywołuje skutek ex nunc" ${ }^{34}$. Pogląd te nie znalazł jednak kontynuacji w innych orzeczeniach Naczelnego Sądu Administracyjnego (dalej: NSA) i nie można stwierdzić występowania w tym zakresie konkurencyjnej linii orzeczniczej.

Dla pełniejszego zobrazowania problemu prawnego należy wskazać na jeden ze stanów faktycznych rozstrzyganych przez sądy w sprawie w obrębie Policji. Funkcjonariusz Policji otrzymał mianowanie do służby stałej 30 grudnia 2013 r. W styczniu 2017 r. otrzymał decyzję przyznającą mu równoważnik za brak lokalu od dnia 28 grudnia 2016 r. Dnia 14 listopada 2017 r. złożył oświadczenie mieszkaniowe ze okres 30 grudnia 2013 r. do 27 grudnia 2016 r., wnosząc o wypłatę równoważnika wstecz. Dnia 29 listopada 2017 r. komendant miejski Policji odmówił wypłaty równoważnika za okres 30 grudnia 2013 r. do 27 grudnia 2016 r. Decyzja ta została podtrzymana przez komendanta wojewódzkiego Policji. Organy uznały, że decyzja w sprawie równoważnika ma charakter konstytutywny i że uprawnienie do równoważnika przysługuje do daty wydania decyzji, która jest wydawana w odpowiedzi na złożenie oświadczenia mieszkaniowego. Nie można jednak przyznać równoważnika za okres wsteczny wskazany w oświadczeniu mieszkaniowym.

Sądy administracyjne, w tym NSA, nie uznały takiej interpretacji i praktyki zastosowanej przez komendantów Policji. NSA ${ }^{35}$ utrzymał w mocy wyrok Wojewódz-

33 Wyrok NSA z dnia 24 sierpnia 2020 r., I OSK 3285/19, Legalis nr 2477768; wyrok NSA z dnia 30 października 2018 r., I OSK 1217/18, Legalis nr 1864296. Deklaratoryjny charakter decyzji potwierdzono także w wyroku NSA z dnia 31 maja 2017 r., I OSK 2572/16, Legalis nr 1604371; wyrok NSA z dnia 30 października 2018 r., I OSK 1217/18, Legalis nr 1864296; wyrok NSA z dnia 21 lipca 2020 r., I OSK 3282/19, Legalis nr 2417483.

34 Wyrok NSA z dnia 14 lipca 2011 r., I OSK 450/11, Legalis nr 382735; wyrok NSA z dnia 14 czerwca 2016 r., I OSK 1258/15, Legalis nr 1586484 (wyrok z 2016 r. dotyczył jednak decyzji w sprawie cofnięcia uprawnienia do równoważnika pieniężnego). Wyrok NSA z dnia 1 stycznia 2019 r., I OSK 3175/18, Legalis nr 2364759. 
kiego Sądu Administracyjnego (dalej: WSA) ${ }^{36} \mathrm{w}$ tej sprawie. NSA podzielił zdanie WSA, że decyzja w sprawie równoważnika za brak lokalu ma charakter decyzji deklaratoryjnej.

Również ustawa o Policji nie stanowi o tym, aby prawo do przedmiotowego świadczenia funkcjonariusz nabywał dopiero od dnia złożenia oświadczenia mieszkaniowego. Innymi słowy $\mathrm{z}$ ustawy tej nie wynika limit czasowy, poza okresem przedawnienia, ograniczający realizację prawa do równoważnika pieniężnego [...]. Z zasady tej wyprowadzić można wniosek, że dla zakresu oddziaływania deklaratoryjnej decyzji administracyjnej „wstecz” znaczenie ma data spełnienia przez adresata decyzji przesłanek uzasadniających możliwość konkretyzacji jego praw lub obowiązków, a nie data wydania decyzji [...]. Uprawnienie funkcjonariusza do przedmiotowego świadczenia należy zatem oceniać bezpośrednio w oparciu o przepisy ustawy o Policji, a prawo do równoważnika pieniężnego należy łączyć jedynie z faktem pełnienia służby stałej oraz brakiem przez funkcjonariusza (członków jego rodziny) lokalu mieszkalnego w miejscu pełnienia służby lub miejscowości pobliskiej. Ustawa o Policji nie formułuje wprost innych w tym zakresie przesłanek. Takich dodatkowych warunków nie można też wyprowadzać w drodze zabiegów interpretacyjnych. „Niedopuszczalne są wszelkie zabiegi interpretacyjne prowadzące do sformułowania dodatkowych przesłanek, mogących w konsekwencji doprowadzić do pozbawienia czy ograniczenia praw podmiotowych przyznanych ustawą)" (por. wyrok Sądu Najwyższego z dnia 13 lutego 1996 r, sygn. akt III AZP 23/95, OSN 1996/15/205) [...]. Zakres delegacji nie upoważniał Ministra do powtórnego ukształtowania prawa do równoważnika za brak lokalu mieszkalnego policjanta, w sposób odmienny od przyjętych rozwiązań ustawowych. Stąd też $\$ 3$ rozporządzenia ${ }^{37}$ w brzmieniu: „Ustalenia uprawnień policjanta do otrzymania równoważnika pieniężnego za brak lokalu mieszkalnego oraz jego wysokości dokonuje się na podstawie oświadczenia mieszkaniowego, którego wzór stanowi załącznik do rozporządzenia" nie może stanowić podstawy prawnej do łączenia ustawowych przesłanek powstania uprawnienia do równoważnika $\mathrm{z}$ datą złożenia tzw. „oświadczenia mieszkaniowego”. Dokument ten ma przede wszystkim znaczenie dowodowe, a ponadto inicjuje postępowanie administracyjne, którego przedmiotem jest ustalenie i skonkretyzowanie uprawnień funkcjonariusza do równoważnika [...]. Uprawnienie do równoważnika za brak lokalu mieszkalnego ma charakter obiektywny, a o tym czy policjantowi w drodze decyzji zostanie on przyznany, decyduje jedynie udokumentowanie spełnienia wszystkich przesłanek ustawowych uprawniających do tego świadczenia. Niewystąpienie przez policjanta z wnioskiem o wypłatę równoważnika powoduje, że równoważnik taki nie jest

36 Wyrok WSA we Wrocławiu z dnia 9 maja 2018 r., IV SA/Wr 154/18, Legalis nr 1776937.

37 Chodzi tutaj o rozporządzenie Ministra Spraw Wewnętrznych i Administracji z dnia 28 czerwca 2002 r. w sprawie wysokości i szczegółowych zasad przyznawania, odmowy przyznania, cofania i zwracania przez policjantów równoważnika pieniężnego za brak lokalu mieszkalnego, tekst jednolity: Dz. U. z 2020 r. poz. 946. 
wypłacany. Nie oznacza to jednak, że policjant traci prawo do tego dodatku z tytułu zgodnego z rzeczywistym stanem rzeczy, tj. za okres nieposiadania powyższego lokalu. Jedynym ograniczeniem są tu przepisy o przedawnieniu, a w szczególności przepis art. $107 \$ 1$ ustawy o Policji ${ }^{38}$.

W orzecznictwie dotyczącym równoważnika za brak lokalu dla funkcjonariuszy służby więziennej nie występuje zagadnienie charakteru prawnego decyzji w tym zakresie.

W orzecznictwie dotyczącym równoważnika za brak lokalu dla funkcjonariuszy służby granicznej wskazano, że decyzja w sprawie równoważnika za brak lokalu ma charakter mieszany.

Sąd w składzie orzekającym przychyla się do stanowiska, iż decyzja o przyznaniu równoważnika za brak lokalu mieszkalnego wydana w niniejszej sprawie jest decyzją konstytutywną, opartą o przesłankę związaną z wymogiem złożenia „wniosku mieszkaniowego", która zaistniała w dniu [...] listopada 2006 r., a więc jeszcze przed jej wydaniem i doręczeniem. Natomiast przyjęcie tezy, że świadczenie to powinno być przyznane z dniem powołania skarżącego do służby stałej [...] lipca 2006 r., tj. dniem spełnienia przez niego przesłanek warunkujących jego otrzymanie, nadawałoby tej decyzji ewidentnie cechy decyzji deklaratoryjnej - jej skutki powstałyby z mocy prawa ze wskazanym dniem ${ }^{39}$.

NSA w Warszawie w wyroku z dnia 6 marca 2002 r., I SA 3350/01, wyraził pogląd o konstytutywnym charakterze decyzji wydawanych w przedmiocie równoważnika w tym zarówno przyznających ten równoważnik, jak i orzekających o utracie ${ }^{40}$.

Funkcjonariusz, spełniający ustawowe warunki przewidziane w art. 96 ust. 1 ustawy, może zatem żądać przyznania mu równoważnika za cały przysługujący mu okres, dopóki nie nastąpi przedawnienie takiego roszczenia. Z powyższych względów nie można przyjąć, że prawo podmiotowe do równoważnika pieniężnego powstaje dopiero od chwili złożenia wniosku mieszkaniowego, o którym mowa w $\$ 2$ pkt 5 cyt. rozporządzenia. Wniosek ten warunkuje jedynie możliwość realizacji przedmiotowego uprawnienia, nie wyznacza natomiast granic okresu za który świadczenie przysługuje. Równoważnik pieniężny za brak lokalu mieszkalnego przyznaje się w drodze decyzji administracyjnej po złożeniu wspomnianego wniosku mieszkaniowego, ale z datą spełnienia przez

Wyrok NSA z dnia 1 stycznia 2019 r., I OSK 3175/18, Legalis nr 2364759. Takie same zapatrywanie prawne wyrażono w wyroku dotyczącym równoważnika w Straży Granicznej, zob. wyrok NSA z dnia 3 grudnia 2008 r., I OSK 1923/07, Legalis nr 197585.

39 Wyrok WSA w Warszawie z dnia 6 listopada 2008 r., II SA/Wa 1202/08, Legalis nr 282366.

40 Por. wyrok WSA w Warszawie z dnia 25 maja 2004 r., I SA 2214/02, Legalis nr 1125387. 
funkcjonariusza ustawowych przesłanek do równoważnika za brak lokalu mieszkalnego w miejscu pełnienia służby stałej lub w miejscowości pobliskiej ${ }^{41}$.

Chociaż NSA nie wyraził wprost zapatrywania co do charakteru prawnego decyzji w sprawie równoważnika, to sposób rozstrzygnięcia zagadnienia wskazuje, że sąd uznał charakter mieszany decyzji w sprawie równoważnika.

\section{Procedura przyznania równoważnika za brak lokalu w PSP}

Równoważnik za brak lokalu mieszkalnego przysługuje w okresie od dnia powstania uprawnienia do jego pobierania do dnia, w którym nastąpiła utrata tego uprawnienia $^{42}$. Uprawnienie do równoważnika za remont albo za brak lokalu mieszkalnego ustala się na podstawie złożonego przez strażaka oświadczenia mieszkaniowego. Uprawnienie do równoważnika za remont ustala się na dzień 1 stycznia każdego roku. Strażak jest obowiązany niezwłocznie zawiadomić, poprzez złożenie oświadczenia mieszkaniowego, o każdej zmianie mającej wpływ na uprawnienie do otrzymania równoważnika za remont albo za brak lokalu mieszkalnego lub na wysokość równoważnika ${ }^{43}$.

Minister właściwy do spraw wewnętrznych określił, w drodze rozporządzenia ${ }^{44}$, tryb przyznawania równoważników za remont albo za brak lokalu mieszkalnego i sposób ustalania ich wysokości oraz wzór oświadczenia mieszkaniowego z uwzględnieniem:

1) stawki równoważnika za remont na normę zaludnienia przysługującej strażakowi,

2) stawki dziennej równoważnika za brak lokalu mieszkalnego, z uwzględnieniem stanu rodzinnego strażaka,

3) terminu wypłaty równoważników,

4) jednostek organizacyjnych właściwych do ich wypłaty ${ }^{45}$.

Równoważnik pieniężny za remont albo za brak lokalu mieszkalnego przyznaje się na podstawie złożonego przez strażaka oświadczenia mieszkaniowego,

41 Wyrok NSA z dnia 3 grudnia 2008 r., I OSK 1923/07, Legalis nr 197585. Orzeczenie to uzyskało poparcie w wyroku NSA z dnia 18 czerwca 2009 r., I OSK 210/09, Legalis nr 238200.

42 Art. 78 ust. 3 u.PSP

43 Art. 79 ust. 2-3 u.PSP

44 Rozporządzenie Ministra Spraw Wewnętrznych i Administracji z dnia 18 listopada 2005 r. w sprawie trybu przyznawania strażakowi Państwowej Straży Pożarnej równoważników pieniężnych za remont albo za brak lokalu mieszkalnego, Dz. U. Nr 241, poz. 2033 (dalej: rozporządzenie z dnia 18 listopada 2005 r.).

45 Art. 79 ust. 6 u.PSP. 
składanego przez niego rzadziej niż raz w roku ${ }^{46}$. Wypłata równoważnika pieniężnego za brak lokalu mieszkalnego następuje do dnia 10 każdego miesiąca za miesiąc poprzedni ${ }^{47}$.

Przepisy nie określają dokładnej daty, kiedy strażak powinien złożyć pierwsze oświadczenie mieszkaniowe. Z przepisów wynika obowiązek złożenia oświadczenia mieszkaniowego nie rzadziej niż raz w roku. Jednak przepisy nie mówią, że powinno być ono złożone w chwili zatrudnienia strażaka. Przepisy dopuszczają więc złożenie oświadczenia mieszkaniowego przez strażaka dopiero kilka miesięcy po zatrudnieniu. Wówczas powstaje sytuacja, że uprawnienie do równoważnika będzie przysługiwało mu na mocy przepisów już w chwili zatrudnienia, ale decyzja w sprawie równoważnika formalnie będzie mogła być wydana, dopiero gdy strażak złoży oświadczenie mieszkaniowe. Wówczas równoważnik będzie mógł być wypłacony, pomimo że prawo do równoważnika może mu przysługiwać wcześniej. Art. 78 ust. 3 u.PSP mówi wprost, że równoważnik za brak lokalu mieszkalnego przysługuje $\mathrm{w}$ okresie od dnia powstania uprawnienia do jego pobierania do dnia, w którym nastąpiła utrata tego uprawnienia. Data powstania uprawnienia bądź data utraty uprawnienia nie jest równa dacie złożenia oświadczenia mieszkaniowego.

Przepisy obligują do niezwłocznego złożenia oświadczenia mieszkaniowego, ale dopiero, gdy jest to kolejne oświadczenie mieszkaniowe w służbie związane ze zmianą mającą wpływ na uprawnienie do otrzymania równoważnika za brak lokalu mieszkalnego lub na wysokość równoważnika.

Rozbieżności pomiędzy datą przysługiwania uprawnienia, a datą wydania decyzji do uprawnienia w postaci równoważnika za brak lokalu powstają także w sytuacji, kiedy w trakcie pobierania równoważnika okaże się, że zaistniały przesłanki do jego utraty. Wówczas data utraty uprawnienia do równoważnika nie będzie tą samą datą, co data wydania decyzji w przedmiocie utraty uprawnienia do równoważnika. Data utraty prawa do równoważnika może być datą wcześniejszą od daty wydania decyzji o kilka miesięcy, a nawet o kilka lat.

Na bazie różnic pomiędzy tymi datami powstaje spór co do charakteru decyzji w sprawie równoważnika za brak lokalu.

$46 \$ 2$ ust. 1-2 rozporządzenia $\mathrm{z}$ dnia 18 listopada $2005 \mathrm{r}$.

$47 \S 4$ ust. 2 rozporządzenia $\mathrm{z}$ dnia 18 listopada $2005 \mathrm{r}$. 


\section{Rozstrzygnięcie problemu charakteru prawnego decyzji w sprawie równoważnika}

W orzecznictwie sądowym dotyczącym równoważnika za brak lokalu dla funkcjonariuszy PSP nie uchwycono istoty tego zagadnienia, tak jak to się dokonało w orzeczeniach dotyczących funkcjonariuszy Policji czy Straży Granicznej. Poglądy na temat charakteru prawnego decyzji w sprawie równoważnika wyrażono w orzeczeniach dotyczących PSP raczej na uboczu głównych zagadnień rozstrzyganych $\mathrm{w}$ tych orzeczeniach.

Należy postawić tezę, że decyzja w sprawie równoważnika za brak lokalu dla funkcjonariuszy PSP ma charakter decyzji mieszanej. Pogląd taki koresponduje z poglądami doktryny prawa odnoszącej się do deklaratoryjności i konstytutywności aktów administracyjnych wyrażonych we wcześniejszych partiach niniejszego artykułu. Co do zasady jest to decyzja deklaratoryjna, jednak z cechami decyzji konstytutywnej. Oznacza to, że procedurę przyznania równoważnika rozpoczyna złożenie przez strażaka oświadczenia mieszkaniowego. Organ administracji publicznej, jakim w tym przypadku będzie komendant powiatowy PSP, powinien zastosować prawo z chwili złożenia oświadczenia mieszkaniowego, kiedy zaistniały przesłanki do przyznania równoważnika $z$ art. 78 ust. 1 u.PSP, a nie przepisy z chwili wydawania decyzji w tym przedmiocie. Decyzja taka będzie potwierdzać jedynie spełnienie przesłanek do przyznania równoważnika, które wynikają z mocy samego prawa, i w tym sensie będzie ona decyzją deklaratoryjną, potwierdzającą jedynie to, co wynika $\mathrm{z}$ samego prawa. W decyzji takiej można zawrzeć, że skutki prawne będą następować z mocą wsteczną (ex tunc) od chwili, kiedy zaistniały przesłanki do wypłaty równoważnika. W takim przypadku wiązać się to będzie z koniecznością wypłaty równoważnika za okres wsteczny.

Element konstytutywny takiej decyzji wyraża się w tym, że potwierdzenie spełniania przesłanek może dokonać się dopiero w momencie wydania takiej decyzji, która jest wydawana na skutek złożenia oświadczenia mieszkaniowego. Przy czym nie będzie ona kształtować sytuacji prawnej strażaka na nowo, a jedynie potwierdzać stan wynikający z przepisów. To potwierdzenie może nastąpić dopiero $\mathrm{w}$ momencie wydania decyzji, a nie w chwili spełnienia przesłanek wskazanych w przepisach.

Uznanie charakteru mieszanego decyzji w sprawie równoważnika wynika $\mathrm{z}$ analizy przepisów regulujących tę instytucję w obrębie PSP. Przepisy jednoznacznie wskazują przesłanki przyznania równoważnika, więc nie ma konieczności, aby decyzja administracyjna w zakresie równoważnika kształtowała sytuację prawną strażaka. Ta sytuacja prawna wynika wprost z przepisów. 
Z praktycznego punktu widzenia należy wskazać, że pierwsze oświadczenie mieszkaniowe strażaka powinno być składane już w momencie zatrudniania go w danej jednostce organizacyjnej PSP. Pozwoli to rozstrzygnąć kwestie przysługiwania równoważnika już w chwili jego zatrudniania i uniknąć tym samym konieczności wypłacania równoważnika wstecz.

Orzeczenia sądowe uznające deklaratoryjny charakter decyzji w sprawie równoważnika są trafne, z zastrzeżeniem, że w swojej treści w większości odwołują się do podziału decyzji na deklaratoryjne i konstytutywne, bez dostrzeżenia poglądów w nauce prawa wskazujących na możliwość mieszanego charakteru decyzji. Koncepcja decyzji mieszanych trafniej rozwiązuje niniejsze zagadnienie. Orzeczenia sądów uznające wyłącznie konstytutywny charakter decyzji należy uznać za nietrafne.

Mieszany charakter ma także decyzja o zwrocie równoważnika. Z tym że w przypadku wydawania tych decyzji należy stosować prawo z chwili zaistnienia przesłanek do zwrotu równoważnika, a nie z chwili złożenia oświadczenia mieszkaniowego lub wydawania decyzji o zwrocie równoważnika. Wynika to $\mathrm{z}$ faktu, że organ rozstrzygający $\mathrm{w}$ tym przedmiocie mógł się dowiedzieć o zaistnieniu przesłanek o zwrocie równoważnika już po złożeniu oświadczenia mieszkaniowego i niezależnie od jego treści. Wówczas w przypadku wszczęcia postępowania w przedmiocie zwrotu równoważnika w jego ramach oświadczenie mieszkaniowe, wskazujące na zaistnienie przesłanek do zwrotu równoważnika, będzie późniejsze niż sama data zaistnienia przesłanek do zwrotu równoważnika.

\section{Bibliografia}

Błaś A., Boć J., Stahl M., Ziemski K., Akty deklaratoryjne a akty konstytutywne, Prawne formy działania administracji, red. R. Hauser, Z. Niewiadomski, A. Wróbel, Warszawa 2013 [baza danych Legalis].

Chrabkowski M., Glosa do wyroku WSA w Warszawie z 30.06.2011 r., II SA/Wa 935/11, Gdańskie Studia Prawnicze. Przegląd Orzecznictwa 2012, nr 3.

Chrabkowski M., Równoważnik pieniężny za brak lokalu mieszkalnego, cz. 1-2, Policja 2012, nr 3 i 4.

Daniel P., Geburczyk F., Akt informacji jako forma działania administracji publicznej, Warszawa 2019 [baza danych Legalis].

Grześków M., Nawiązywanie stosunków zatrudnienia w stużbach zmilitaryzowanych, Warszawa 2020 [baza danych Legalis].

Szustakiewicz P., Świadczenia pieniężne związane z prawem do lokalu mieszkalnego emerytów i funkcjonariuszy stużb mundurowych $w$ orzecznictwie sądów administracyjnych, IUSNOVUM 2013, nr 3. 